\title{
一般薄肉断面の曲りばりの解析
}

\section{ANALYSIS OF THIN WALLED CURVED BEAM}

\author{
倉西茂* \\ By Shigeru Kuranishi
}

要 旨 円弧状に曲った薄肉断面のはりの変形, 応 力などの解析法を示したものである。溥肉断面の直ばり の解析手法にしたがい，はりの幅の影響を入れて断面諸 定数などを求めている。はりの軸に沿った母線の間に働 く直応力度の影響は入れられていないが, 直ばり場合と 同程度の仮定のもとに本解析は行なわれている。

また本方法による曲線橋の解析方法が示されている。

\section{1.はじめに}

曲りばりのその面内での問題はラーメン隅角部の応力 分布の問題，あるいはフックの曲げの問題などとして筸 より数多く取り扱われて米た。わが国でもこの方面の研 究としては故大野諌博士の研究 ${ }^{33,4), 5)}$ がある。面外への 変形についてもリング, コイルバネの問題, アーチの面 外一の変形問題 ${ }^{14)}$, 円環基礎の問題 ${ }^{8)}$ としてやはり数多 く取り扱われて米た。特に曲線橋の発達につれて最近こ の方面の研究がさかんに行なわれて米ている。

文献 9）は著者らによる直ばり断面定数を用いた場台 の曲りばりの解析, 文献 15) は文献 9）を発展させ曲線 格子桁の一解法を示している。文献 10) は直ばりの断面 ではなく，曲率の影響を，すなわち曲率半径方向の幅の 影響も考えて 2 本主析の曲線橋を解く方法を報告してい る。文献 16）は小西教授，小松助教授によって閉じた断 面の薄肉曲りばりの基礎理論を示している。

しかし文献 16) は断面として閉じた断面のものに限ら れ，開いた断面のものについては触れられてない，また 直ばりとの関連という点にわいて十分でないように思わ れる。本論文は文献 16) と一部重複する所もあるが，特 に直ばりの理論之同じ考え方のもとに，断面形不変の場 合の曲りばりの面外への変形問題について開いた断面も ふくめて一般的解析を行なったものである。合成桁のよ うにヤング率の異なる部材がふくまれる場合，多室の閉 断面の場合などについては触れていないが，乙れは文献 2），16）を参照しても，また直ばりの手法を知っていれ ば簡単に発展させるととができるものと思われる。

また最後に本理論を基にした曲線橋の解析基礎理論を 述べている。

\section{2. 曲りばりの応力}

$*$ 正員 工博 東北大学助教授 工学部土木工学科

\section{(1) 座 標 系}

こてで取り扱っている曲りばりははり軸方向の母線 が，ある垂直軸を中心とする円弧となっているもので， はり内にその垂直 軸がふくまれない ものである。また はりの曲率半径方 向の幅は曲率半径 の数倍以上のもの とする。

座標軸としては 今述べた垂面軸を $\bar{z}$ 軸とし極座標を 図一1 に示したよ うにとる。曲 げ変形によっ て伸びも縮も しない軸を中 站軸とし，そ の半径を $R_{0}$ とし, 中立軸 を原点として 断面に $r$ 軸方

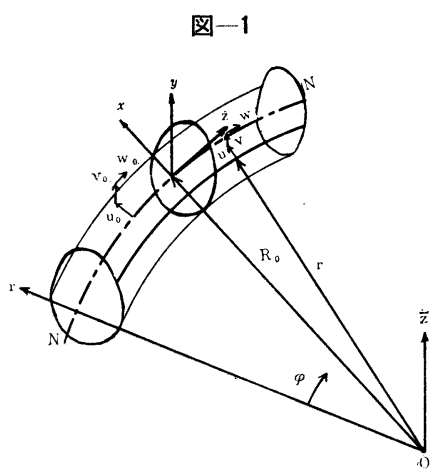

図一2
向に $x$ 軸, $\bar{z}$ 軸方向に $y$ 軸, $\varphi$ 軸方向に $z$ 軸をとる。ま た断面主軸は $z$ 軸を中心としてねじ回りに $\theta$ だけ回転し た方向にあるものとする。各点の $(r, \bar{z}, \varphi)$ 方向の変 位をそれぞれ $(u, v, w)$ とする。また断面中立軸の変 位はそれぞれ $\left(u_{0}, v_{0}, w_{0}\right)$ とする。ねじり角 $\beta$ は $\varphi$ の增 加方向を見て逆時計回りに回転するものを正とする。

\section{(2) 単純曲 げ}

断面形は不変とし，はり軸に直父している断面は単純 曲げに対しては変形後も直交しており，軸方向直応力度 の算出に対しては平面を保っているものとする。この仮 定は特に曲りばりの場合にははり軸に直角方向の応力な ぞが働くので直ばりの場合より成立しにくいと思われ る。しかし薄板の面内曲げの場合で変形後の断面が平面 であるとした場合と，箃密解との差は中立軸の曲率半径 と同程度の幅をもったものでも $7 \%$ 程度に 過ぎないの で，中立軸の曲率半径に比してはりの幅が数分の一であ れば十分正確に成立するものと思われる。 
曲りばりの各母線の $\boldsymbol{r}$ 軸, $\bar{z}$ 軸回りの曲率の変化を $k_{r}, k_{z}$ とし, はり軸回りのねじり率の増加を $k_{\varphi}$ とする とそれぞれ次式で与えられる。

または $\quad=\frac{1}{r^{2}} u^{\prime \prime}+\frac{1}{r^{2}} u+\frac{1}{r} \varepsilon_{\varphi}$

$$
\begin{aligned}
k_{r} & =\frac{1}{r^{2}} v^{\prime \prime}-\frac{1}{r} \beta \\
k_{z} & =\frac{1}{r^{2}} u^{\prime \prime}+\frac{1}{r^{2}} w \\
& =\frac{1}{r^{2}} u^{\prime \prime}+\frac{1}{r^{2}} u+ \\
k_{\varphi} & =\frac{1}{r} \beta^{\prime}+\frac{1}{r^{2}} v^{\prime}
\end{aligned}
$$

ここで，'は $\varphi$ について微分したてとを表わし， $\varepsilon_{\varphi}$ は 円周方向のひずみを表わす。

単純曲げ, すなわち直ばりと同ように各母線ともねじ り率が生じない変形を考えると

$$
\frac{1}{r} \beta^{\prime}+\frac{1}{r^{2}} v^{\prime}=0
$$

はり軸と断面が直交していることより, 断面各点の変位 は中立軸の変位 $u_{0}, v_{0}, w_{0}$ とねじれ角 $\beta$ で書き表わさ れる。

$$
\left.\begin{array}{l}
u=u_{0}+y \beta \\
v=v_{0}-x \beta \\
w=-\frac{u_{0}^{\prime}}{R_{0}} x-\frac{v_{0}^{\prime}}{R_{0}} y+\frac{r}{R_{0}} w_{0}
\end{array}\right\}
$$

円周方向の直ひずみは

$$
\varepsilon_{\varphi}=\frac{1}{r} u+\frac{1}{r} w^{\prime}
$$

で与えられる。中立軸では

$$
\frac{u_{0}}{R_{0}}+\frac{1}{R_{0}} w_{0}^{\prime}=0
$$

式 (4) に式 (3) を代入して整理すると

$$
\varepsilon_{\varphi}=-\frac{R_{0}}{r} y k_{r_{0}}-\frac{R_{0}}{r} x k_{z_{0}}
$$

が得られる。ただし $k_{r_{0}}, k_{z_{0}}$ は中立軸での $k_{r}, k_{z}$ の值 である。また他のひずみ，直ひずみ $\varepsilon_{r}$ ， せん断ひずみ $\psi_{r \varphi}, \psi_{r z}, \psi_{\varphi z}$ は 0 となる。

よって直応力度は

$$
\sigma_{\varphi}=\frac{E}{1-\nu^{2}} \varepsilon_{\varphi}
$$

で与えられる。

曲げモーメントと曲率の 関係ですでに 文献 6)，16） で述べられているが，本論文の記号にしたがいあらため て書くと次式で与えられる。

$$
\left.\begin{array}{rl}
M_{y} & =\frac{E}{1-\nu^{2}} k_{r_{0}} I_{x y}+\frac{E}{1-\nu^{2}} k_{z_{0}} I_{y} \\
M_{x} & =\frac{E}{1-\nu^{2}} k_{r_{0}} I_{x}+\frac{E}{1-\nu^{2}} k_{z_{0}} I_{x y}
\end{array}\right\}
$$

$R_{0}$ は $\int_{A} \frac{y}{r} d A=0, \quad \int_{A} \frac{x}{r} d A=0$

より定められる。

式 (8) を書き直すと

$$
\begin{aligned}
& \frac{E}{1-\nu^{2}} k_{r_{0}}=\frac{M_{x} I_{y}-M_{y} I_{x y}}{I_{x} I_{y}-I_{x y}{ }^{2}} \\
& \frac{E}{1-\nu^{2}} k_{z_{0}}=\frac{M_{y} I_{x}-M_{x} I_{x y}}{I_{x} I_{y}-I_{x y}{ }^{2}}
\end{aligned}
$$

今 $x, y$ 軸より $\theta$ だけ時計回りと回転した軸 $\xi, \eta$ 軸 に断面主軸があるとすれば

$$
\left.\left.\begin{array}{l}
x=\xi \cos \theta-\eta \sin \theta \\
y=\xi \sin \theta+\eta \cos \theta
\end{array}\right\} \begin{array}{l}
\xi=x \cos \theta+y \sin \theta \\
\eta=y \cos \theta-x \sin \theta
\end{array}\right\}
$$

より, $\xi, \eta$ 軸回りの曲げモーメントは

$$
\left.\begin{array}{rl}
M_{\xi} & =\frac{E}{1-\nu^{2}}\left(k_{r_{0}} I_{\xi} \cos \theta-k_{z_{0}} I_{\xi} \sin \theta\right) \\
M_{\eta} & =\frac{E}{1-\nu^{2}}\left(k_{r_{0}} I_{\eta} \sin \theta+k_{z_{0}} I_{\eta} \cos \theta\right)
\end{array}\right\}
$$$$
\text { ここで } I_{\xi}=\int_{A} \frac{R_{0}}{r} \eta^{2} d A
$$

式 (13) より $k_{r_{0}}, k_{z_{0}}$ を定めると

$$
\left.\begin{array}{l}
k_{r_{0}}=\frac{1-\nu^{2}}{E} \frac{I_{\eta} M_{\xi} \cos \theta+I_{\xi} M_{\eta} \sin \theta}{I_{\xi} I_{\eta}} \\
k_{z_{0}}=\frac{1-\nu^{2}}{E} \frac{I_{\xi} M_{y} \cos \theta-I_{\eta} M_{\xi} \sin \theta}{I_{\xi} I_{\eta}}
\end{array}\right\}
$$

式（15）を式 (16)，(17）に入れ, 式 (12) の関係を 考えて整理すると

$$
\sigma_{\varphi}=-\frac{R_{0}}{r} \frac{\xi}{I_{\eta}} M_{\eta}-\frac{R_{0}}{r} \frac{\eta}{I_{\xi}} M_{\xi}
$$

を得る。

(3) 曲げ応力 によるせん 断応力

球座標による応 力のつりあい式よ り与えられるが, 今与えているだけ の応力についてつ りあいを求めると 図一3に示したよ うに $\varphi$ 方向の力の 平衡より

$$
\text { 图-3 }
$$

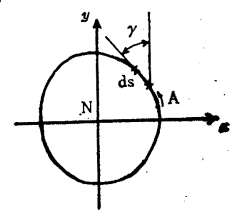

$$
\begin{array}{r}
\left(\sigma+\frac{\partial \sigma}{\partial \rho} d \varphi\right) t \cdot d s-(\sigma \cdot t \cdot d s)+\tau t \cdot r d \varphi \\
-\left(\tau+\frac{\partial \tau}{d s} d s\right)(r-d s \sin r) t \cdot d \varphi
\end{array}
$$




$$
+\left(\tau+\frac{\partial \tau}{\partial \varphi} d \varphi\right) t d s \sin r d \varphi=0
$$

$\therefore \frac{\partial(\sigma t)}{\partial \varphi} d \varphi \cdot d s+2(\tau t) \sin r d s d \varphi$

$$
-\frac{d(\tau t)}{d s} r d s d \varphi=0
$$

ここで $d s$ は直ばりと同じ法則にしたがい断面の周网に 沿って訃る。 $t$ は板厚である。

$$
\begin{aligned}
& \text { 今 } \left.\sin r=-\frac{d r}{d s} \downarrow り\right) \\
& \quad \frac{\partial(\sigma t)}{\partial \varphi}-2(\tau t) \frac{d r}{d s}-\frac{d(\tau t)}{d s} r=0 \cdots \cdots(17 \cdot \mathrm{a}) \\
& \therefore \quad \frac{\partial(\sigma t)}{\partial \varphi}=\frac{d\left(\tau t r^{2}\right)}{r d s} \cdots \cdots \cdots \cdots \cdots \cdots \cdots(17 \cdot \mathrm{b})
\end{aligned}
$$

今それぞれの主軸回りの曲げモーメントを考えると， ねじりモーメント0なる状態を考えているのであるか ら，図一4に示す上うに $\xi$ 軸 $\eta$ 軸に直侍方向のせん断

图-4

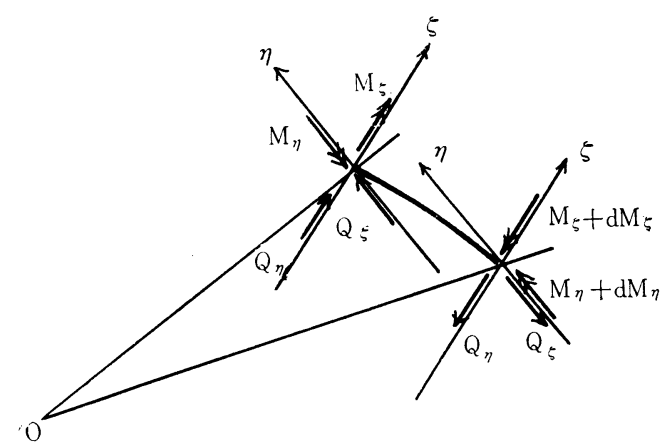

力を $Q_{\xi} Q_{\eta}$ とすれば

$$
\frac{d M_{\xi}}{r d \varphi}=-Q_{\xi}, \frac{d M_{\eta}}{r d \varphi}=-Q_{\eta}
$$

なる関係がある。今 $M_{\eta}$ のみについて考えると

$$
\begin{aligned}
\frac{\partial(\sigma t)}{\partial \varphi} & =-\frac{R_{0}}{r} \frac{\xi t}{I_{\eta}} \cdot \frac{\partial M_{\eta}}{\partial \varphi} \\
& =R_{0} \frac{\xi t}{I_{\eta}} \cdot Q_{\eta} \cdots \cdots \cdots
\end{aligned}
$$

よって $R_{0} \frac{\xi t}{I_{\eta}} Q_{\eta}=\frac{1}{r} \frac{d\left(\tau t r^{2}\right)}{d s}$

せん断流は式 (21) を積分して

$$
\tau t=\frac{R_{0} Q_{\eta}}{r^{2} I_{\eta}} \int r \cdot \xi t d s+C_{\eta}
$$

と得られる。積分定数 $C_{\eta}$ は開いた断面では $\tau=0$ の点 より積分を始めれば $C_{\eta}=0$ となる。测じた断面ではせ ん断力による断面のそりが断面を一湖してもとの值にも どることにより定められる。 $M_{\xi}$ についても同しような 関係が得られ

$$
\tau t=\frac{R_{0} Q_{\xi}}{r^{2} I_{\xi}} \int r \cdot \eta \cdot t d s+C_{\xi}
$$

となる。

今図一5 に示すように断面のはり軸方闹の変位を $\bar{w}$, 周囲の接線方向の変位を $\bar{v}$ とすれ゙，はり軸方向の 2

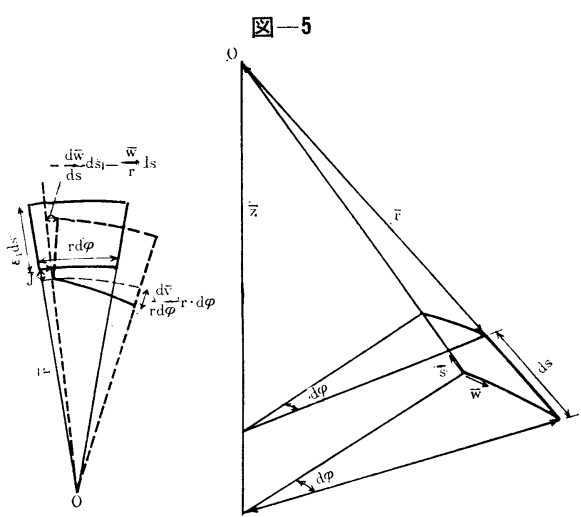

本の母線と 2 つの断面とによって切り出される側面の微 小部分の受けるせん断ひずみ廿は

$$
\psi=-\frac{d \bar{w}}{d s}-\frac{\bar{w}}{r}-\frac{d \bar{v}}{r d \varphi} .
$$

で与えられる。今とてで

$$
\left.\begin{array}{l}
\bar{w}=w \quad \bar{v}=-u \sin r+v \cos r \\
\bar{r}=\frac{r}{\sin r} \quad \sin r=-\frac{d r}{d s}
\end{array}\right\}
$$

なる関係がある。

はり断面はこの曲げによるせん断力により平面状態よ り $w_{b}$ だけそると考えれば式 (3) は

$$
\begin{aligned}
& u=u_{0}+y \beta \\
& v=v_{0}-x \beta \\
& v=w_{b}-\frac{u_{0}^{\prime}}{R_{0}} x-\frac{v_{0}^{\prime}}{R_{0}} y+\frac{r}{R_{0}} w_{0}
\end{aligned}
$$

とwは $w_{b}$ だけ増加した形となる。

式 (23・a), 式 (24) の関係を式 (23) に入れて整理 すると

$$
\begin{aligned}
\psi=- & \frac{d w_{b}}{d s}+\frac{w_{b}}{r} \frac{d r}{d s}+\frac{\beta^{\prime}}{r}(y \sin r+x \cos r) \\
& +\frac{v_{0}^{\prime}}{R_{0} r}(y \sin r+x \cos r) \cdots \cdots \cdots \cdots \cdots(25)
\end{aligned}
$$

ここではねじり率 0 なる変形を考えているのであるから

$$
\beta^{\prime}+\frac{v_{0}^{\prime}}{R_{0}}=0
$$

より式（25）は

$$
\begin{aligned}
\psi & =-\frac{d w_{b}}{d s}+\frac{w_{b}}{r} \frac{d r}{d s} \\
& =-r \frac{d}{d s}\left(w_{b} \cdot r^{-1}\right)
\end{aligned}
$$

よって $\frac{\tau}{G}=-r \frac{d}{d s}\left(w_{b} r^{-1}\right)$

$w_{b}$ は積分を一周して元の值にもどることにより

$$
\int \frac{\tau}{r G} d s=0
$$

より積分定数は定められる。また式 (26) はせん断おく れの形を見るときにも役立てることができる。

式 (27), 式 (22) よりせん断応力の 分布が定まれば 
せん断中心の位置を定めることができる。文献 16)では せん断中心を曲げねじりによる直応力度によって曲げモ ーメントが生じないてとより定めているが，こてでは一 般の直ばりの解法にしたがい曲げによるせん断応力度の 中心にとる。

\section{(4) 単純ねじり}

はりの各母線はねじり変形のみを受け曲げ変形を受け ない場合を考える。またねじり率は変化せずはりに直応 力度は働かないものとする。

式 (18) より直応力度が㗢いていない時のせん断流は $\frac{d\left(\tau t r^{2}\right)}{d s}=0$

$$
\text { より } \tau t=\frac{C_{q}}{r^{2}}
$$

なる形で与えられる。

今せん断中心位置でのはりの変位を $u_{s}, v_{s}, w_{s}$ とし， その座標を $\left(R_{s}, \varphi, \bar{z}_{s}\right)$ で表わす。せん断中心に新たに $x, y$ 軸に平行に $x_{s}, y_{s}$ 軸をとり, 断面平面よりの断面 のそりを $w_{s}$ とすれば式 (25) で $w_{b}$ を求めたときと 同じような操作により

$$
\begin{aligned}
\psi= & -r \frac{d}{d s}\left(w_{s} r^{-1}\right)+\frac{\beta^{\prime}}{r}\left(y_{s} \sin r+x_{s} \cos r\right) \\
& +\frac{v_{s}{ }^{\prime}}{R_{s} r}\left(y_{s} \sin r+x_{s} \cos r\right) \ldots \ldots \ldots \ldots \ldots \ldots
\end{aligned}
$$

とせん断ひずみは求められる。

今せん断中心より周辺におろした垂線の長さをdとす れば,

$$
d=y_{s} \sin \gamma+x_{s} \cos \gamma
$$

よって式 (30) は次式となる。

$$
\begin{aligned}
\psi & =-r \frac{d}{d s}\left(w_{s} r^{-1}\right)+\frac{d}{r} \frac{R_{s}}{R_{s}}\left(\beta^{\prime}+\frac{v_{s}^{\prime}}{R_{s}}\right) \\
& =-r \frac{d}{d s}\left(w_{s} r^{-1}\right)+\frac{R_{s} \cdot d}{r} k_{\varphi s} \cdots \cdots \cdots
\end{aligned}
$$

$k_{\varphi s}$ はねじり中心軸でのねじり率を表わす。

$$
\text { よって } \frac{\tau}{G}=-r \frac{d}{d s}\left(w_{s} r^{-1}\right)+\frac{R_{s} \cdot d}{r} k_{\varphi s}
$$

開いた断面では $\tau t=0$ より断面のそりは

$よ b$

$$
\frac{d}{d s}\left(w_{s} r^{-1}\right)=\frac{R_{s} \cdot d}{r^{2}} k_{\varphi s}
$$

$$
w_{s}=R_{s} r \cdot k_{\varphi s} \int \frac{d}{r^{2}} d s+C_{s} \cdot r
$$

で与えられる。積分定数 $C_{s}$ は軸方向力が無いことより

$$
\int_{s} \frac{w_{s} t}{r} d s=0
$$

\section{より定めることができる。}

閉じた断面では断面周迅上の 2 点 $A, B$ でのそりの差 は

$$
\begin{aligned}
& \left(\frac{w_{s}}{r}\right)_{A}-\left(\frac{w_{s}}{r}\right)_{B} \\
& =-\int_{A}^{B} \frac{\tau}{G r} d s+R_{s} k_{\varphi s} \int_{A}^{B} \frac{d}{r^{2}} d s
\end{aligned}
$$

で与えられる。今断面に働いているねじりモーメントを $M^{T}$ とすれば

$$
M^{T}=\oint \tau \cdot t d d s=\oint \frac{C_{q}}{r^{2}} \cdot d \cdot d s
$$

で与えられるゆえ

$$
2 F=R_{s}^{2} \oint \frac{d}{r^{2}} d s, C_{q}=\frac{R_{s}{ }^{2}}{2 F} M^{T}, \tau=\frac{R_{s}}{2 F r^{2} t} M^{T}
$$

と置けば式 (36) は

$$
\begin{aligned}
& \left(\frac{w_{s}}{r}\right)_{A}-\left(\frac{w_{B}}{r}\right)_{B} \\
& =-\int_{A}^{B} \frac{M^{T}}{G \cdot 2 F t r^{3}} d s+R_{s} k_{\varphi s} \int_{A}^{B} \frac{d}{r^{2}} d s(36 \cdot \mathrm{a})
\end{aligned}
$$

となる。

閉じた断面では，断面を一周して積分すれば 初の值にもどるゆえ, 式 (36・a) は

$$
-\oint \frac{R_{s}{ }^{2} M^{T}}{G 2 F t r^{3}} d s+R_{s} \cdot k_{\varphi s} \oint \frac{d}{r^{2}} d s=0 \text {. }
$$

となり, 結局ねじりモーメントとねじり率の関係は次式 で与えられる。注1),2)

$$
\frac{M^{T}=G \cdot J_{T} k_{\varphi s}}{G J_{T}=\frac{4 F^{2}}{R_{s}{ }^{3} \oint \frac{1}{G r^{3} t} d s}}
$$

開いた断面では备母線のねじり凨性の和であるなら

$$
G J_{T}=R_{s} \int_{s} \frac{G t^{3}}{r} d s
$$

\section{(5) 曲げねじり}

閉じた断面では，断面上の一点に $s$ の原点をとり，そ の点での断面のそりを $w_{s 0}$, 曲率半径を $r_{0}$ とすれば, 任 意の点での断面のそりは

$$
\begin{aligned}
w_{s}= & \frac{r}{r_{0}} w_{r_{0}}-r \frac{2 F}{R_{s}{ }^{3} \oint \frac{1}{G r^{3} t} d s} \cdot k_{\varphi s} \int_{0}^{s} \frac{1}{G t r^{3}} d s \\
& +R_{s} r k_{\varphi} s \int_{0}^{s} \frac{d}{r^{2}} d s \ldots \ldots \ldots \ldots \ldots \ldots \ldots \ldots \ldots \ldots \ldots \ldots
\end{aligned}
$$

で与えられる。

この断面のそりの変化による直応力度は

$$
\sigma=\frac{E}{1-\nu^{2}}\left(\varepsilon_{s}+\frac{w_{s}^{\prime}}{r}\right)
$$

で与えられる。ここで $\varepsilon_{s}$ はせん断中心軸のひずみであ る。軸力 0 より

$$
\oint \sigma t d s=0
$$

よって

$$
\oint\left(\frac{w_{s 0}{ }^{\prime}}{r_{0}}+\varepsilon_{s}\right) t d s-\left\{\frac{2 F}{R_{s}{ }^{3} \oint \frac{1}{G r^{3} t} d s} \oint t \int_{0}^{s} \frac{1}{G t r^{3}} d s d s\right.
$$

注 1）ねじり剛性は小西・小松の一室の暏合と一致する。

注 2) ねじりにともなうせて断力の項注省略している。 


$$
\left.-R_{s} \oint t \int_{0}^{s} \frac{d}{r^{2}} d s d s\right\} k_{\varphi s}{ }^{\prime}=0
$$

今

$$
\frac{1}{r_{0}} w_{s 0}{ }^{\prime}+\varepsilon_{s_{0}}=C_{0} R_{s} k_{\varphi s^{\prime}}
$$

と置けば

$$
\begin{aligned}
C_{0} \oint t \cdot d s & =\frac{2 F}{R_{s}{ }^{4} \oint \frac{d s}{G r^{3} t}} \oint t \int_{0}^{s} \frac{1}{G t r^{3}} d s d s \\
& -\oint t \int_{0}^{s} \frac{d}{r^{2}} d s d s \ldots \ldots \ldots \ldots \ldots \ldots \ldots \ldots \ldots \ldots \ldots \ldots
\end{aligned}
$$

で $C_{0}$ は与えられる。

よって直応力度は

$$
\sigma=\frac{E W}{1-\nu^{2}} R_{0} k_{\varphi s^{\prime}}
$$

で与えられる。ここで

$$
W=C_{0}-\frac{2 F}{R_{s}{ }^{4} \oint \frac{d s}{G r^{3} t}} \int_{0}^{s} \frac{d s}{G t r^{3}}+\int_{0}^{s} \frac{d}{r^{2}} d s
$$

である。てのとき桁のもっている全ポテンシャルエネ ルギー $V$ は次式で与えられる。

$$
\begin{aligned}
& V=\frac{1}{2} \int_{0}^{\alpha} \oint \frac{1-\nu^{2}}{E} \sigma^{2} \cdot t \cdot r d s d \varphi \\
& +\frac{1}{2} \int_{0}^{\alpha} G J_{T} k_{\varphi}{ }^{2} R_{s} d \varphi-\int_{0}^{\alpha} M^{T} k_{\varphi s} \cdot R_{s} d \varphi \\
& \text { 今 } \quad C_{b d}=\oint W^{2} R_{s}{ }^{3} t \cdot r d s
\end{aligned}
$$

と置き，断面は全スパンにわたり一定とすれば $\delta V=0$ よ?

$$
-\frac{E}{1-\nu^{2}} \frac{C_{b d}}{R_{s}{ }^{2}} k_{\varphi s}{ }^{\prime \prime}+G J_{T} k_{\varphi}=M^{T}
$$

を得る。式 (49) を書きかえれば

$$
\begin{gathered}
-\frac{E}{1-\nu^{2}} C_{b d} \frac{1}{R_{s}{ }^{3}}\left(\beta^{\prime \prime \prime}+\frac{1}{R_{s}} v_{s^{\prime \prime}}{ }^{\prime \prime}\right) \\
+\frac{G J_{T}}{R_{s}}\left(\beta^{\prime}+\frac{1}{R_{s}} v_{s}{ }^{\prime}\right)=M^{T} \ldots
\end{gathered}
$$

を得る。

せん断流は式 (18)より

$$
\begin{aligned}
\frac{\partial(\sigma t)}{\partial \varphi} & =\frac{d\left(\tau t r^{2}\right)}{r \cdot d s} \\
& =\frac{W R_{s}}{1-\nu^{2}} k_{\varphi s}{ }^{\prime \prime}
\end{aligned}
$$

積分定数は式 (27) と同ように

$$
-\oint \frac{\tau}{G r} d s=0
$$

より定める。開いた断面では式 (41) の右迊第 2 項を 0 と置き, 後の操作は閉じた断面と同じようにして曲げね ビり剛性を求めることができる。

\section{3. 曲りばりの変形}

式 (11) より $r$ 軸回りの曲げに対しては

$$
\frac{1}{R_{0}^{2}} v_{0}^{\prime \prime}-\frac{1}{R_{0}} \beta=\frac{1-\nu^{2}}{E} \frac{M_{x} I_{y}-M_{y} I_{x y}}{I_{x} I_{y}-I_{x y}{ }^{2}}
$$

ねじりに対しては式（50）より

$$
\begin{gathered}
-\frac{E C_{b d}}{1-\nu^{2}} \frac{1}{R_{s}{ }^{3}}\left(\beta^{\prime \prime \prime}+\frac{1}{R_{s}} v_{s}^{\prime \prime \prime}\right) \\
+\frac{G J_{T}}{R_{s}}\left(\beta^{\prime}+\frac{1}{R_{s}} v_{s}^{\prime}\right)=M^{T}
\end{gathered}
$$

A $v_{0}$ と $v_{s}$ の間の関係は式 (3)より

$$
v_{0}=v_{s}+\left(R_{s}-R_{0}\right) \beta
$$

と書ける。乙の関係を式 (54) に入れると

$$
\begin{aligned}
\frac{1}{R_{0}{ }^{2}} v_{s}^{\prime \prime} & +\frac{\left(R_{s}-R_{0}\right)}{R_{0}{ }^{2}} \beta^{\prime \prime}-\frac{\beta}{R_{0}} \\
= & \frac{1-\nu^{2}}{E} \frac{M_{x} I_{y}-M_{y} I_{x y}}{I_{x} I_{y}-I_{x y}{ }^{2}}
\end{aligned}
$$

よりねじり角 $\beta$ は

$$
\begin{gathered}
-\frac{E C_{b d}}{1-\nu^{2}} \frac{R_{0}}{R_{s}{ }^{4}}\left(\beta^{\mathrm{N}}+\beta^{\prime \prime}\right)+G J_{T} \frac{R_{0}}{R_{s}{ }^{2}}\left(\beta^{\prime \prime}+\beta\right) \\
=M^{T^{\prime}}+\frac{C_{b d} R_{0}{ }^{2}}{R_{s}{ }^{4}} \frac{M_{x}{ }^{\prime \prime} I_{y}-M_{y}{ }^{\prime \prime} I_{x y}}{I_{x} I_{y}-I_{x y}{ }^{2}} \\
-\frac{\left(1-\nu^{2}\right) G J_{T}}{E} \frac{R_{0}{ }^{2}}{R_{s}{ }^{2}} \frac{M_{x} I_{y}-M_{y} I_{x y}}{I_{x} I_{y}-I_{x y}{ }^{2}}
\end{gathered}
$$

で与えられる。 $\beta$ が求められれば $v_{s}, v_{0}$ は式 (54), (55)より求められる。曲りばりの面内の曲げに対して は式(15) がそのまま使用できる。

\section{4. 多主桁の曲線橋への応用}

いくつかの主栴を剛な横枌で結合しているような形式 の曲線桁の解析には当然本論文の方法が適用できる。し かしててではもう少し式の簡略化を行なうため三，三の 条件をつけることにする。第一に各主桁の断面定数は直 桁としてのものを用い，曲率半径方向の幅の影響は考え ない。つぎに各主桁の中立軸は同一の水平面内にあるも のとする。主析は外側より $1,2,3 \cdots \cdots \cdot \cdots n$ と数え諸定 数の右下にその番号をつける。

4 $C_{b k}=\frac{E C_{b d k}}{R_{k}{ }^{3}}, T_{k}=\frac{G J_{T k}}{R_{k},}, K_{k}=\frac{E I_{k}}{R_{k}{ }^{2}}$

なる諸量を考え，本論文で行なったのと同じ方法により 働いている荷重と変形の間の方程式を求めると

$$
\begin{aligned}
& -C_{b}\left(\beta^{\mathrm{N}}+\beta^{\prime \prime}\right)+T\left(\beta^{\prime \prime}+\beta\right) \\
= & -\left(1+\frac{T}{\bar{R} K}+\frac{C_{b_{0}}}{\bar{R} K}\right) M-\frac{C_{b_{0}}}{\bar{R} K}(R+e) w-e w
\end{aligned}
$$

を得る。

ことで

$$
\begin{aligned}
C_{b} & =\Sigma \frac{\left(R_{k}-\bar{R}\right)^{2}}{R_{k}} K_{k}+\Sigma\left(\frac{\bar{R}}{R k}\right)^{2} C_{b k} \\
T & =\Sigma\left\{\left(\frac{\bar{R}}{R_{k}}\right)^{2} T_{k}\right\} \\
C_{b_{0}} & =\Sigma \bar{R} \frac{\left(\bar{R}-R_{k}\right)}{R_{k}} K_{k}+\Sigma\left(\frac{\bar{R}}{R_{k}}\right)^{2} C_{b k} \\
K & =\Sigma K_{k} \\
\bar{R} & =\frac{\sum R_{k} K_{k}}{K}
\end{aligned}
$$


荷重は中立軸をふくんでいる水平面に垂直な荷重と し, 単位角度当りの荷重強度をwとし, 怔げモーメン ト $M$ ははりを下方に向って凸にするものを正とする。 $R_{k}$ は外側より $k$ 番目の主枌のせん断中心軸の曲率半径 である。eは $\bar{R}$ より荷重までの距離を表わし, 外側に あるものを正とする。

式 (60)より荷重が与えられればねじり角 $\beta$ は求め られる，ゆえに各主桁に㗢く曲げモーメントは

$$
M_{k}=\frac{K_{k}}{K} M-\frac{K_{k}}{K}\left(R_{k}-\bar{R}\right)\left(\beta^{\prime \prime}+\beta\right)
$$

で与えられる。この形の $k=2$ の場合は著者によって文 献 10) に報告 されている。

横析は主桁

間にいちよう に分布してい るものと考え ているのであ るから，単位 角度当り主桁 との間に働い ている垂直反 力 $w_{k}$, ねじ りモーメント $m_{k} T^{T}$ 図一6

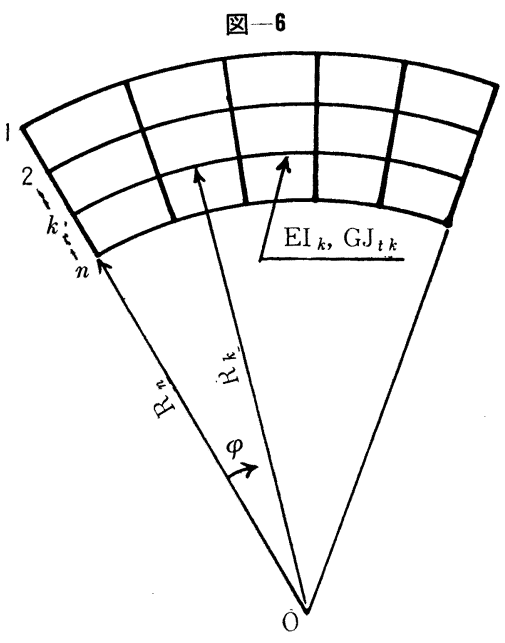

に示したように

$$
\begin{aligned}
w_{k}= & \frac{T_{k}}{R_{k} K} M-\left(\frac{C_{b k}}{R_{k} K}+\frac{K_{k}}{K}\right) M^{\prime \prime}+\frac{T_{k} \bar{R}}{K_{k}}\left(\beta^{\prime \prime}+\beta\right) \\
& +\left\{\frac{K_{k}}{K}\left(\bar{R}-R_{k}\right)-\frac{C_{b k} \bar{R}}{R_{k}}\right\}\left(\beta^{\prime \prime \prime \prime}+\beta^{\prime \prime}\right) \\
-m_{k} T & =\left(\frac{K_{k}}{K}+\frac{T_{k}}{R_{k} K}\right) M-\frac{C_{b k}}{R_{k} K} M^{\prime \prime} \\
& +\left\{\frac{T_{k} \bar{R}}{R_{k}}-\frac{K_{k}}{K}\left(R_{k}-\bar{R}\right)\left(\beta^{\prime \prime}+\beta\right)\right. \\
& \left.-\frac{C_{b k} \bar{R}}{R_{k}}\right\}\left(\beta^{\prime \prime \prime \prime}+\beta^{\prime \prime}\right)
\end{aligned}
$$

と変形より与えられる。横桁は一般には主桁間にいちよ うに分布しているわけではないから，各横桁は横析間に 働いている分をそれぞれ受けもつと考えて計算する。

また主桁が全体として受ける曲げモーメントと析の変 形との関係は次式で与えられる。

$$
M=K\left(v^{\prime \prime}-\bar{R} \beta\right)
$$

\section{図-7}

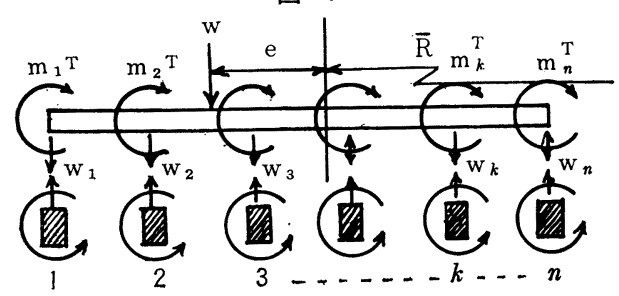

ここで $v$ は $r=\bar{R}$ 軸での変位である。

\section{4.あとがき}

溥肉断面の直ばりと同ように, 曲げ応力度の胡算に は薄板のせん断変形を考えず，また效じりに対しては断 面のそりの変化によって生じる直応力度に対してもせん 断変形を考えないという手法によって薄肉曲りばりの解 析を行なったものである。もちろん曲りばりでははり輯 方向の母線間に応力が働き, 曲率半径方向の応力度を生: じるが，一般断面でこの佔を正確に計算するのは困難で あるし，断面の変形防止に入っているダイヤフラムの影 響を正確にとり入れるのも困難なので省略して計算し た。この曲率半径方向に生じる応力によって I 形桁など では横桁間で突然の変形を起しし，その面内でかなりの 曲げ応力を生じるがその值は文献 9）などに述べた方法 などにより近似的に計算できる。箱形断面の析のカバー プレートに働くこの応力は文献 5) などの公式を準用し て近似的に求めることができるものと思われる。

一般には主桁は曲りの影響を受けて闹じ断面の直ばり よりたわみが大きいため，相対的に横桁の剛性が大きく なり，横析の変形はあまり主桁に㗢く曲げモーメントに 影響しないため，多主析の曲線橋により近似で適用でき るものと思われる。この形のものはすでに小松定夫助教 授らによって発表されているもの之一部類似のものとな ったが，本論文の一般断面のものと同一の考えで処理で きるのであえて報告した。多 I 形主桁合成曲線橋の場合 にコンクリート床版に曲率半径方向の応力が働くのでそ の值の一応の目安をつけておくことも必要と思われる。

\section{参考文 献}

1) Timoshenk, S \& Goodier J.N. : “Thesry of Elasticity" McGraw-Hill, 1951.

2）食西正嗣：“灾用弾性学”, 共立, 1953.

3）大野 諌：“曲線の剪断応力度および半径方向の 垂直応

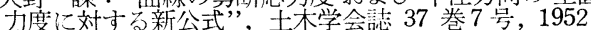

4）大野諌：“鋼ラーメン隅角部の志力度分布”、士木学会 誌 39 巻 2 号, 1954 .

5）大野 諌：“曲ばりの半径方向の檕直応力度公式”, 土木 学会誌 39 巻 1 号, 1954.

6) Biezeno, C.B. \& Grammel, R. : "Technische Dynamik" Springer, 1939.

7) Anderson, C.G. : "Flexural stresses in curved beams of I and box-sections", 1950, Applied Mechanics, London.

8) Troy, E.V. : “Deflection of Circulan Beams Resting on Elastie Foundutions Obtained by Methods of Harmonic Analysis", Journal of Applied Mechanics 1953 June.

9）平井・倉西: “曲線橋の理論について”, 土朴技術, 13 巻 7 号, 1958.

10）平井・含西：“幼線橋について”，第 4 回日本道路会議論 文集, 1957 .

11）倉西・鎌田：“白糸曲線橋架橋工事およびその他につい 会”, 土技術 13 卷 8 号, 1958 .

12) Wansleben, E.H.F.: "Die Theorieder Drillfestigkeit von Stahlbanteilen", Stahlban, 1956

13) Cutts, C.E. : "Honizontal Curved Box Beans, A.S. C.E., No. 128, 1952.

14）倉西 茂: “水平横荷重を受けるアーチ橋について”, 土 采学会論文集 73 号, 1961 .

15）会西茂：“曲線格子桁の解法”, 土木学会論文集 76 号, 1961.

16）小西・ 小松: “薄肉曲線桁の基礎理論”, 土木学会論文集 87 号, 1962 .

（1964.2.5 - 受付） 